\title{
Genetic Advancement and Variability of Released Common Bean (Phaseolus vulgaris L.) Varieties from 1974-2009 GC in Ethiopia
}

\author{
Nigussie Kefelegn (D), ${ }^{1}$ Frew Mekibib, ${ }^{2}$ and Yigzaw Dessalegn ${ }^{3}$ \\ ${ }^{1}$ Debre Birehan Agricultural Research Center, Crop Research Directorate, Debre Berhan, Ethiopia \\ ${ }^{2}$ Haramaya University, Department of Plant Science, Haramaya, Ethiopia \\ ${ }^{3}$ Lives Project, International Livestock Research Institute (ILRI), Bahir Dar, Ethiopia \\ Correspondence should be addressed to Nigussie Kefelegn; nigussie555@gmail.com
}

Received 7 February 2020; Revised 12 November 2020; Accepted 3 December 2020; Published 18 December 2020

Academic Editor: Othmane Merah

Copyright (c) 2020 Nigussie Kefelegn et al. This is an open access article distributed under the Creative Commons Attribution License, which permits unrestricted use, distribution, and reproduction in any medium, provided the original work is properly cited.

\begin{abstract}
The efficiency of variety development can be determined with variability and genetic progress of released varieties. The aim of this study was to determine the variability and genetic advancement of common bean varieties. Randomized Completed Block Design was used to evaluate 15 varieties at Koga and Chefa in 2013. Cluster, principal, and biplot analysis including genetic parameter estimation were done following analysis of variance. Significant variation was observed among the varieties, and they are clustered into four groups. Seed color and size were found as an important factors for clustering of the varieties. Hawassa Dume and Nasir have red and small seeded, respectively, and clustered in one group. Similarly, Awash 1 and Awash Melka are both small white and clustered in one group. Hawassa Dume was highly similar to Nasir, and Red Wolayta with Dimitu, while a large distance was recorded between Awash Melka and Haramaya. Deme and Haramaya were found the most divergent and unique among the tested varieties. This is also reflected in biplot drown by principal components 1 and 2, which together accounted for about 82.022. Plant heights, seed weight, days to maturity, and harvest index have the largest contribution to the total variation of the varieties. Most of the traits have a high phenotypic and genotypic coefficient of variation, heritability, and genetic advance, and selection was effective in the breeding program. The breeding program has brought about 0.27 tonnes of seed yield increment or an annual rate of genetic progress of $0.0077 \mathrm{tha}^{-1}\left(0.37 \% \mathrm{ha}^{-1}\right.$ year $\left.^{-1}\right)$. However, the breeding program should reconsider the breeding procedure as there are some varieties released in the same year with similar genetic potential.
\end{abstract}

\section{Introduction}

Haricot bean is the most economically important warm season pulse crop grown in Ethiopia. Currently, commercial farming of haricot bean is growing though it is usually grown by subsistence farmers as a sole crop or intercropped with other crops. Considering the production volume and importance, it can be considered as a major pulse crop in the low and mid-altitudes of the country. A continuous increase in area and volume of production has been noticed due to the growing demand for the local and export market. The national production of haricot bean in 2013/14 cropping season was 457 thousand tonnes, with a production area of 326 thousand hectares [1] and increased to 521 thousand tonnes on an area of 306.2 thousand hectares in $2017 / 18$ cropping season [2].

Yield and yield contributing parameters are the most widely targeted traits not only for common bean but also for other field crop improvement. Yield is a complex polygenic character, resulting from multiple interactions between yield contributing traits. The selection of desirable types should, therefore, be based on yield as well as on other yield components. Associations between these traits can be evaluated by correlation or biplot analysis, which helps in the simultaneous selection for more than one character [3]. A critical assessment of genetic variability and character association in crop genetic resources is one of the important prerequisites in formulating efficient breeding methods [4]). 
The improvement of a crop is largely dependent on the nature and magnitude of available genetic variability, heritability, and the transfer of desired characters into new varieties. The success of breeding programs can be enhanced when variability within the existing germplasm is high, which allows the plant breeder to rapidly produces new varieties or improve existing ones [5]. Knowledge of genetic variability, heritability, and genetic advance provides more reliable information on variability, heritable trait, nature, and level of the interrelationship of common bean yield and yield components [6]. Genetic parameters like the genotypic coefficient of variation (GCV), phenotypic coefficient of variation (PCV), heritability, and genetic advance (GA) are useful biometric tools for measuring genetic variability [7].

To increase farmers' bean productivity and also to respond to their varied needs and preferences, the national bean program of Ethiopia has been developing and making available improved common bean varieties with improved yield potential and resistance to important biotic and abiotic constraints. In the previous bean research, the bean breeding program mainly focuses on identifying widely adapted varieties while the contemporary program becomes more inclusive. The breeding program gives additional attention to market class or seed color and seed size. In the Ethiopian bean breeding program, about 57 common bean varieties were registered since 1973 [8]. To determine the efficiency of the breeding program, it is important to measure the variability, genetic advance/yield gain, and association of those registered varieties in line with the breeding objectives. The effectiveness of selection in any crop depends on the extent and nature of phenotypic and genotypic variability present in different agronomic traits [9]. Therefore, this research work was designed to measure the genetic variability, genetic advance, and association based on some of the popular common bean varieties using their important traits.

\section{Material and Methods}

The experiment was conducted at Chefa from eastern Amhara and Koga from western Amhara, experimental locations of Amhara Agricultural Research Institute, Ethiopia, during 2013 cropping seasons. The description of each testing site is indicated in Table 1.

Fifteen common bean varieties were tested in this experiment, and the details of them are indicated in Table 2. The experiment was laid out in a randomized complete block design with three replications. The size of the experimental plot was $6.4 \mathrm{~m}^{2}(1.6 \mathrm{~m} \times 4 \mathrm{~m})$, with an inter- and intrarow spacing of $0.4 \mathrm{~m}$ and $0.1 \mathrm{~m}$. Planting was carried out from the first week of July up to mid-July in 2013. Seeds were hand-drilled in rows and later thinned to $0.1 \mathrm{~m}$ between plants to maintain 40 seedlings per row. Fertilizer was not applied, and weeding and other agronomic practices were done as required. Agronomic, phonologic, and morphological traits of each variety were collected following Phaseolus vulgaris L. descriptor [10].

2.1. Data Analysis. Combined analysis of variance (ANOVA) and least significant difference (LSD) were computed for all traits using Genstat version 18 for identification of the significant difference between varieties. Genetic parameters such as phenotypic and genotypic coefficient of variation, heritability, and genetic advances were estimated by the formula given by [11-13] for the individual testing locations. Cluster analysis was done using Ward's method on past V3.2 software. With similar software, principal component and biplot analysis were done. Moreover, the data were analyzed to determine dissimilar groups (clusters) of the varieties using Euclidean distance and trend analysis also carried out using Microsoft Excel.

\section{Result and Discussion}

Combined analysis of variance revealed there was a highly significant difference among the varieties for yield and yield contributing components. This indicates the presence of a good amount of genetic variability within the released common bean varieties in Ethiopia. The overall performance of the varieties from the combined analysis is indicated in Table 3.

\subsection{Analysis of Genetic Parameters. According to [11], PCV} and GCV values greater than $20 \%$ are regarded as high, whereas values less than $10 \%$ are considered to be low and values between 10 and $20 \%$ to be moderate. An estimate of the genetic parameter for different traits of the varieties at both testing locations is presented in Table 4. The highest genotypic and phenotypic variations were recorded for plant height, seed weight, seed yield, and harvest index at both locations. The result agrees for seed yield but disagrees for harvest index and seed weight with the findings of [14]. The breeding program was effective in the development of varieties regarding the abovementioned traits. Arora [9] mentioned that the effectiveness of selection in any crop depends on the extent and nature of phenotypic and genotypic variability present in different agronomic traits of the population. However, selection of days to maturity, days to flowering, and pod length was not effective in the bean breeding program of Ethiopia. The genotypic and phenotypic coefficients of variation for these traits are below $12 \%$. Generally, the GCV and PCV were similar in magnitude and direction in both locations, which indicated that the varieties were able to express their genetic potential for various traits. A similar result was reported by [14].

The broad sense heritability is more than $70 \%$ for all of the traits at Chefa and only 5 out of all the measured traits have more than $60 \%$ at Koga. The maximum heritability $\left(h^{2} B\right)$ estimates were $100 \%$ and $87 \%$, whereas the minimum heritability was $71 \%$ and $5 \%$ at Chefa and Koga, respectively. According to [15], heritability values are categorized as low from 0 to $30 \%$, moderate from 30 to $60 \%$, and $60 \%$ and above are high. Based on these scholars, the heritability of all traits at Chefa was very high. On the other hand, 5 of the traits showed high heritability, 4 of the traits showed moderate heritability and only one trait has very low heritability at Koga (Table 4). High heritability values for most of the traits indicated that the variation observed was mainly under 
TABLe 1: Rainfall, soil type, altitude, latitude, and longitude of the testing sites.

\begin{tabular}{|c|c|c|c|c|c|c|}
\hline \multirow{2}{*}{ Locations } & \multirow{2}{*}{ Altitude (m.a.s.l.) } & \multirow{2}{*}{ Temp. (min and $\max$ in ${ }^{\circ} \mathrm{C}$ ) } & \multirow{2}{*}{ Rainfall average $(\mathrm{mm})$} & \multirow{2}{*}{ Soil type } & \multicolumn{2}{|c|}{ Global position } \\
\hline & & & & & Latitude & Longitude \\
\hline Chefa & 1400 & $11.6-30.4$ & 850 & Vertisol & $10^{\circ} 57^{\prime}$ & $39^{\circ} 47^{\prime}$ \\
\hline Koga & 1900 & $16-20$ & 1589 & Nitisol & $11^{\circ} 25^{\prime}$ & $37^{\circ} 17^{\prime}$ \\
\hline
\end{tabular}

Source: Sirinka and Debre Birhan Agricultural Research Centers for altitude, rainfall, and soil types, Wikipedia for global position. NA=not available.

TABLE 2: Description of common bean varieties.

\begin{tabular}{|c|c|c|c|}
\hline Variety & Seed color & Seed size & Year of release \\
\hline Tabor & Gray & Small & $1998 / 99$ \\
\hline Hawassa dume & Red & Small & 2008 \\
\hline Dimutu & Red & Small & 2003 \\
\hline Nasir & Red & Small & 2003 \\
\hline Deme & R.speckled & Large & 2008 \\
\hline Awash Melka & White & Small & $1998 / 99$ \\
\hline $\mathrm{Roba}^{-1}$ & Gray & Small & 1990 \\
\hline Zebra & W.speckled & Medium & $1998 / 99$ \\
\hline Awash $^{-1}$ & White & Small & 1990 \\
\hline Red Wolayita & Red & Small & 1974 \\
\hline Bobe red & Red & Medium & 2006 \\
\hline Wodo & Gray & Large & 2003 \\
\hline Lehode & White & Large & 2009 \\
\hline Chercher & Red & Medium & 2006 \\
\hline Haramaya & Cream & Large & 2006 \\
\hline
\end{tabular}

TAвLE 3: Mean value of yield and yield related traits combined over the location (Chefa and Koga).

\begin{tabular}{|c|c|c|c|c|c|c|c|c|c|c|}
\hline Varieties & DF & $\mathrm{DM}$ & NPP & NSP & $\mathrm{PH}$ & PL & Bmtha & SW & Sytha & $\mathrm{HI}$ \\
\hline Tabor & 51.0 & 93.0 & 12.2 & 5.6 & 50.4 & 11.0 & 6.9 & 22.0 & 2.8 & 39.0 \\
\hline Hawassa dume & 46.7 & 83.8 & 13.1 & 4.5 & 35.0 & 9.9 & 6.3 & 23.3 & 3.0 & 46.3 \\
\hline Dimutu & 51.7 & 88.8 & 12.1 & 5.2 & 47.4 & 9.2 & 7.4 & 21.9 & 2.4 & 34.4 \\
\hline Nasir & 44.7 & 83.2 & 13.0 & 5.7 & 35.9 & 9.5 & 5.7 & 20.4 & 2.4 & 42.6 \\
\hline Deme & 49.0 & 92.3 & 6.8 & 3.0 & 53.3 & 11.5 & 4.7 & 42.6 & 1.0 & 21.0 \\
\hline Awash melka & 55.7 & 91.5 & 12.4 & 5.7 & 29.7 & 8.9 & 5.4 & 17.7 & 2.2 & 38.6 \\
\hline $\mathrm{Roba}^{-1}$ & 51.7 & 88.0 & 13.8 & 5.6 & 43.5 & 10.1 & 6.2 & 18.6 & 2.4 & 42.7 \\
\hline Zebra & 48.7 & 87.8 & 11.4 & 4.6 & 41.7 & 8.7 & 5.5 & 25.3 & 1.5 & 28.7 \\
\hline Awash $^{-1}$ & 50.2 & 87.2 & 14.5 & 5.4 & 39.6 & 8.3 & 5.2 & 14.7 & 1.7 & 33.6 \\
\hline Red Wolayita & 49.8 & 89.5 & 11.4 & 4.6 & 44.2 & 9.0 & 7.3 & 20.9 & 2.1 & 30.3 \\
\hline Bobe red & 54.8 & 91.3 & 9.9 & 4.7 & 44.5 & 9.3 & 6.4 & 20.2 & 2.6 & 37.9 \\
\hline Wodo & 47.0 & 88.3 & 9.7 & 4.4 & 44.4 & 10.4 & 6.2 & 33.7 & 2.5 & 35.7 \\
\hline Lehode & 49.2 & 91.3 & 10.1 & 3.4 & 49.5 & 10.6 & 6.1 & 37.7 & 2.2 & 37.4 \\
\hline Chercher & 55.5 & 88.5 & 13.4 & 4.9 & 40.8 & 8.9 & 6.8 & 18.4 & 2.4 & 35.6 \\
\hline Haramaya & 50.5 & 98.7 & 11.6 & 4.3 & 71.0 & 9.5 & 5.9 & 29.8 & 2.4 & 43.9 \\
\hline GM & 50.4 & 89.6 & 11.7 & 4.8 & 44.7 & 9.7 & 6.1 & 24.5 & 2.2 & 36.5 \\
\hline LSD & $2.6^{* *}$ & $4.5^{* *}$ & $2.7^{* *}$ & $1.0^{* *}$ & $6.7^{* *}$ & $1.0^{* *}$ & $1.6^{* *}$ & $4.1^{* *}$ & $0.5^{* *}$ & $12.8^{* *}$ \\
\hline $\mathrm{CV}$ & 2.7 & 2.8 & 13.4 & 9.1 & 8.2 & 6.7 & 16.4 & 10.5 & 12.6 & 21.7 \\
\hline
\end{tabular}

DF-days to flowering, DM-days to maturity, NPP-number of pod per plant, NSP-number of seed per pod, PH-plant height in $\mathrm{cm}$, PL-pod length in $\mathrm{cm}$, Bmtha-biomass ton per hectare, SW-seed weight in gm, Sytha-seed yield ton per ha, HI.

genetic control and was less influenced by the environment and the possibility of genetic progress from selection. Similar studies by $[16,17]$ showed that most traits of common be genotypes showed high heritability. Wondwosen and Abebe [14] also found that most traits of common bean varieties have high heritability value.

High $\mathrm{h}^{2} \mathrm{~B}$, along with high GAM, is an important factor for predicting the effect of selecting the best individuals. The estimate of genetic advance is more useful as a selection tool when considered jointly with heritability estimates [12]. In this study, almost all the traits except days to flowering, days to maturity, number of seed per pod, and pod length have high heritability value coupled with high genetic advance (as a percentage of the mean) at Chefa. Reference [14] also showed that these traits have high heritability with high genetic advance as a percentage of the mean. Seed weight showed the highest heritability coupled with the highest genetic advance at Koga. whereas the least heritability value, as well as genetic advance, was observed for harvest index followed by days to maturity at Koga. However, high 
TABLE 4: Estimate of genetic parameters for yield and yield related traits of 15 common bean varieties.

\begin{tabular}{|c|c|c|c|c|c|c|c|c|c|c|c|c|c|c|}
\hline \multirow{2}{*}{ Traits } & \multicolumn{7}{|c|}{ Chefa } & \multicolumn{7}{|c|}{ Koga } \\
\hline & Mean & $\delta^{2} \mathrm{~g}$ & $\delta^{2} \mathrm{p}$ & GCV & PCV & $\mathrm{h}^{2} \mathrm{~B}$ & GAM & Mean & $\delta^{2} \mathrm{~g}$ & $\delta^{2} \mathrm{ph}$ & GCV & PCV & $\mathrm{h}^{2} \mathrm{~B}$ & GAM \\
\hline $\mathrm{DF}$ & 48.6 & 29.3 & 31.8 & 11.1 & 11.6 & 0.92 & 22.0 & 52.2 & 10.1 & 11.8 & 6.1 & 6.6 & 0.86 & 11.6 \\
\hline $\mathrm{DM}$ & 79.5 & 36.3 & 44.5 & 7.6 & 8.4 & 0.82 & 14.1 & 99.6 & 4.8 & 8.9 & 2.2 & 3.0 & 0.54 & 3.3 \\
\hline NPP & 14.3 & 8.2 & 10.2 & 20.0 & 22.3 & 0.80 & 37.0 & 9.1 & 2.4 & 5.3 & 17.0 & 25.3 & 0.45 & 23.6 \\
\hline NSP & 4.9 & 0.5 & 0.7 & 14.4 & 17.1 & 0.71 & 25.1 & 4.7 & 0.8 & 1 & 19.0 & 21.3 & 0.80 & 35.1 \\
\hline $\mathrm{PH}$ & 57.1 & 292.8 & 304.5 & 30.0 & 30.6 & 0.96 & 60.5 & 32.4 & 32.2 & 47.6 & 17.5 & 21.3 & 0.68 & 29.7 \\
\hline $\mathrm{PL}$ & 10.2 & 1.1 & 1.3 & 10.3 & 11.2 & 0.85 & 19.5 & 9.1 & 0.7 & 1.3 & 9.2 & 12.5 & 0.54 & 13.9 \\
\hline ВTHa & 7.1 & 1.6 & 2.2 & 17.8 & 20.9 & 0.73 & 31.3 & 5.1 & 1.4 & 2.7 & 23.2 & 32.2 & 0.52 & 34.4 \\
\hline SW & 22.9 & 54.2 & 56.6 & 32.1 & 32.9 & 0.96 & 64.8 & 26.1 & 75.1 & 85.9 & 33.2 & 35.5 & 0.87 & 64.0 \\
\hline Sytha & 2.9 & 0.7 & 0.7 & 28.9 & 28.9 & 1.00 & 59.4 & 1.7 & 0.3 & 0.4 & 32.2 & 37.2 & 0.75 & 57.5 \\
\hline HI & 38.7 & 68.4 & 84.6 & 21.4 & 23.8 & 0.81 & 39.6 & 34.4 & 5.2 & 114.2 & 6.6 & 31.1 & 0.05 & 2.9 \\
\hline
\end{tabular}

$\delta^{2} \mathrm{~g}$ : Genotpic variance, $\delta^{2} \mathrm{p}$ : phenotypic variance, GCV: Genotypic Coefficient of Variance, PCV: Phenotypic Coefficient of Variance, $\mathrm{h}^{2} \mathrm{~B}$ : broad sense heritability, GAM: Genetic Advance in Percent of the Mean.

heritability and high genetic advance (as percentage of the mean) were observed only for plant height, seed weight, and seed yield at both locations. High values of genetic advance are indicative of additive gene action, whereas low values are indicative of nonadditive gene action [18]. The finding of this research, in most cases, indicates traits have high heritability coupled with high genetic advance at both locations, indicating that additive gene action is predominantly involved in the expression of various polygenic characters. This reflected that the involvement of additive gene action for the inheritance of these traits and selection was effective in the development of varieties in the breeding program.

3.2. Cluster Analysis. Cluster analysis using all the ten morphological traits grouped the 15 varieties into four major groups at the genetic distance of 15 as indicated in Figure 1. It was also found that, among the four clusters, cluster I was the largest and consisted of 7 varieties, and the second largest was cluster II that consisted of 4 varieties. Cluster IV consists of only one variety. The clustering analysis showed that most released varieties are highly related to their morphological performance. Moreover, the result depicted that seed size and color are an indicator of the resemblance or dissimilarity of the genetic makeup of varieties. The study in [19] showed similar grouping with seed color of common bean genotypes. Lima et al. [19], quoting Rodrigues et al., showed that black seed genotypes were grouped into the same cluster. Sinkovic [20] reported that accessions with similar colors were considered as one cluster. Overall, this study confirmed that varieties with similar seed color and size could be grouped in the same cluster and highly resemble each other.

The euclidian distance and the mean value of the ten traits of the cluster are indicated in Tables 5 and 6, respectively. The smallest euclidian distance was 11.9 , and it is recorded between clusters I and II, indicating their close relationship. These clusters have shown similar performance especially with mean seed yield, pod length, and the number of seeds per plant, while they have the least similar performance with their plant height, as indicated in Table 6. The largest distance was recorded between Cluster II and IV, and they are mainly characterized by small white and red seed (cluster II), and creamy and large seed for cluster IV. The

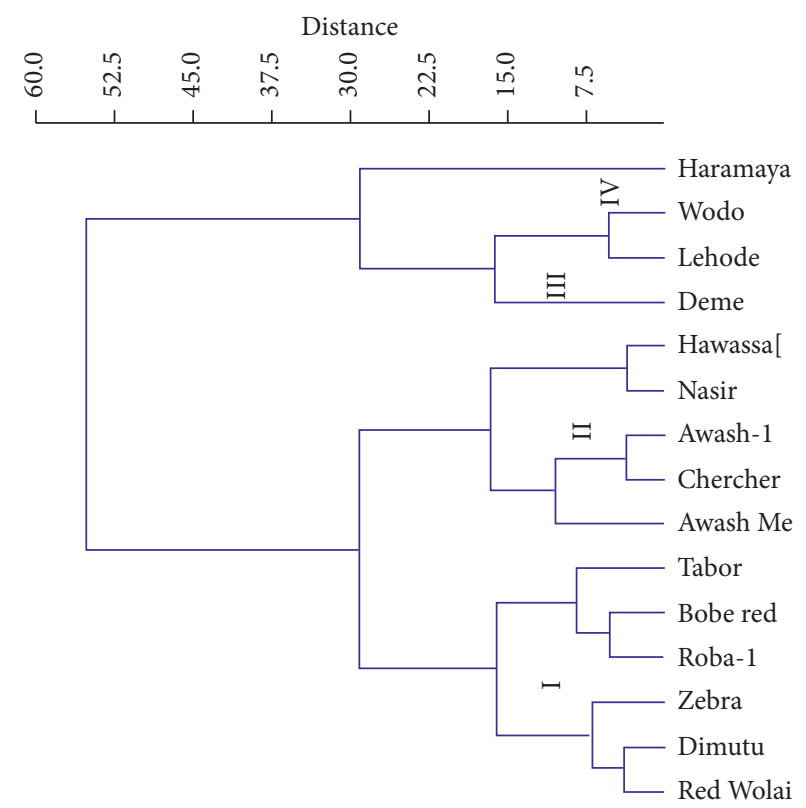

FIgURE 1: Dendrogram showing the relationship among 15 soybean genotypes using yield and yield related traits.

TABLE 5: Similarity and distance indices between groups using Euclidian distance.

\begin{tabular}{lcccc}
\hline Clusters & I & II & III & IV \\
\hline I & 0.0 & & & \\
II & 11.9 & 0.0 & & \\
III & 20.5 & 28.6 & 0.0 & \\
IV & 30.6 & 39.7 & 28.7 & 0.0 \\
\hline
\end{tabular}

distance between these clusters is 39.7 , with a large difference among the traits in plant height. The formation of these groups is very important for choosing parents in breeding programs, once the varieties in more distant groups are dissimilar and may be considered promising to develop new varieties as [21] quoted Peluzio et al. 2009).

Crosses between distantly related clusters and individuals are expected to be more heterotic than those between 
TABLE 6: Mean values of yield and yield related traits for seven groups revealed by cluster analysis among 15 common bean varieties.

\begin{tabular}{|c|c|c|c|c|c|c|c|c|c|c|}
\hline Traits & DF & DM & NPP & NSP & $\mathrm{PH}$ & PL & Btha & SW & Sytha & $\mathrm{HI}$ \\
\hline I & 51.7 & 89.5 & 12.0 & 5.0 & 44.6 & 9.4 & 6.7 & 21.3 & 2.3 & 35.0 \\
\hline II & 49.3 & 86.4 & 13.3 & 5.4 & 35.1 & 9.2 & 5.7 & 19.1 & 2.4 & 40.3 \\
\hline III & 48.6 & 91.1 & 8.4 & 3.5 & 50.2 & 11.0 & 5.4 & 39.2 & 1.7 & 28.8 \\
\hline IV & 50.5 & 98.7 & 11.6 & 4.3 & 71.0 & 9.5 & 5.9 & 29.8 & 2.4 & 43.9 \\
\hline
\end{tabular}

TABLE 7: Similarity and distance indices between groups using euclidian distance.

\begin{tabular}{|c|c|c|c|c|c|c|c|c|c|c|c|c|c|c|c|}
\hline Varieties & & 1 & 2 & 3 & 4 & 5 & 6 & 7 & 8 & 9 & 10 & 11 & 12 & 13 & 14 \\
\hline Tabor & 1 & & & & & & & & & & & & & & \\
\hline Hawassa dume & 2 & 20.0 & & & & & & & & & & & & & \\
\hline Dimutu & 3 & 7.2 & 18.7 & & & & & & & & & & & & \\
\hline Nasir & 4 & 19.1 & 5.4 & 16.9 & & & & & & & & & & & \\
\hline Deme & 5 & 28.4 & 38.4 & 26.6 & 37.6 & & & & & & & & & & \\
\hline Awash melka & 6 & 21.9 & 16.2 & 19.4 & 15.9 & 39.7 & & & & & & & & & \\
\hline $\mathrm{Roba}^{-1}$ & 7 & 10.1 & 12.3 & 10.0 & 11.6 & 35.1 & 15.5 & & & & & & & & \\
\hline Zebra & 8 & 15.3 & 19.6 & 9.6 & 17.1 & 23.4 & 19.1 & 16.2 & & & & & & & \\
\hline Awash $^{-1}$ & 9 & 15.8 & 17.0 & 11.4 & 13.3 & 35.0 & 13.6 & 11.0 & 12.4 & & & & & & \\
\hline Red Wolayita & 10 & 11.6 & 19.8 & 5.8 & 17.1 & 26.2 & 18.3 & 13.2 & 6.0 & 9.6 & & & & & \\
\hline Bobe red & 11 & 8.1 & 17.4 & 6.7 & 16.6 & 30.4 & 15.3 & 8.0 & 13.1 & 11.6 & 9.5 & & & & \\
\hline Wodo & 12 & 15.2 & 18.5 & 13.5 & 18.5 & 20.3 & 24.0 & 17.8 & 11.7 & 20.7 & 14.4 & 16.1 & & & \\
\hline Lehode & 13 & 16.3 & 23.9 & 16.9 & 24.7 & 18.0 & 29.2 & 21.6 & 17.6 & 26.2 & 19.3 & 19.1 & 7.7 & & \\
\hline Chercher & 14 & 12.8 & 16.5 & 8.6 & 15.0 & 32.7 & 12.1 & 8.7 & 12.2 & 7.3 & 9.2 & 6.6 & 18.3 & 22.7 & \\
\hline Haramaya & 15 & 23.4 & 39.8 & 28.5 & 40.0 & 32.8 & 44.3 & 31.7 & 35.1 & 38.3 & 32.7 & 30.1 & 30.2 & 25.1 & 35.3 \\
\hline
\end{tabular}

closely related genotypes. Therefore, prior knowledge of the genetic distance between genotypes or varieties is very important in designing a successful hybridization program. Hence, hybridization activities between clusters II and IV would be more heterotic than those between clusters I and II. For example, cluster III for seed size and cluster IV for yield can be crossed and heterozygous offspring would be obtained either for yield and seed size or for both traits.

The relationship of individual plants using euclidian distance is indicatied in Table 7. Variety Haramaya has the largest genetic distance with variety Awash Melka followed by Nasir. A cross between these individuals can produce heterozygous offspring and would become very important for the breeding program. The most closely related varieties were Hawassa Dume and Nasir, both are small red seeded varieties and grouped in the same cluster. Red wolayta and Dimitu are also highly related and clustered in the same group. Hawassa Dume was released by Awasa Agricultural Research Center in 2008, while Nasir and Dimitu were released in 2003 and Red Wolayta in 1974 by Melkasa Agricultural Research Center. The finding of this research suggested that the national bean research program has some weaknesses in developing varieties. Varieties with the same seed color, size, and overall agronomic performance have been released to the national common bean farming system, which could increase the unnecessary cost of seed multiplication regarding finance, land, and other related costs. Among the tested common bean varieties, Deme and Haramaya are the most divergent and unique varieties. Both varieties have a large euclidian distance from all other varieties.
3.3. Principal Component Analysis. The existence of genotypic variability in 15 varieties was further confirmed by PCA analysis. The Eigenvalue for the first principal component accounted for 58.464 of total variation and the second principal component accounted for 23.558 and together, they accounted for 82.022 of the total variation (Table 8 ). The first principal component is mostly influenced by plant height, seed weight, and days to maturity, while the second component is influenced by harvest index, seed weight, and plant height. A trait with a coefficient greater than 0.3 had a largerly enough effect and was considered as an important trait. Traits having less than 0.2 coefficient value were considered to have no effect on the overall variation [22]. Thus, only plant height, seed weight, and days to maturity in PCA 1 and harvest index, seed weight, and plant height in PCA 2 have found large contribution to the total variation of the varieties (see also Figure 2).

The plot of PCA 1 and PCA 2 shows the relationship among the observation per varieties. Haremaya and Deme were the most unique varieties of all the varieties. Their uniqueness is mostly described by characters like seed weight and plant height, respectively. In a biplot analysis, the correlation coefficient between any of the two characters can be approximated by the cosine of the angle between the vectors [23]. Two characters are positively correlated if the angle between vectors is $<90$, negatively correlated if the angle is $>90$, and independent if the angle is 90 [24]. Based on these scholars number of seeds and pod per plant, days to flowering, harvest index, seed yield, and biomass yield have a high positive correlation while they have a negative correlation with pod length and seed weight. Pod length is highly and positively correlated with seed 
TABLE 8: Eigenvalues and percentage of variation for corresponding two-component characters in 15 genotypes of common bean.

\begin{tabular}{lcc}
\hline Component & PC 1 & PC 2 \\
\hline Eigenvalue & 133.283 & 53.707 \\
\% Variance & 58.464 & 23.558 \\
Character & Eigenvector & \\
Days to flowering & -0.044 & 0.108 \\
Days to maturity & 0.237 & 0.179 \\
Number of pod plant & -0.119 & 0.143 \\
Number of seed per plant & -0.052 & 0.049 \\
Plant height & 0.754 & 0.495 \\
Pod length & 0.045 & -0.025 \\
Biomass yield in ton per hectare & -0.008 & 0.039 \\
Seed weight in gram & 0.565 & -0.466 \\
Seed yield in ton per hectare & -0.014 & 0.045 \\
Harvest index & -0.184 & 0.684 \\
\hline
\end{tabular}

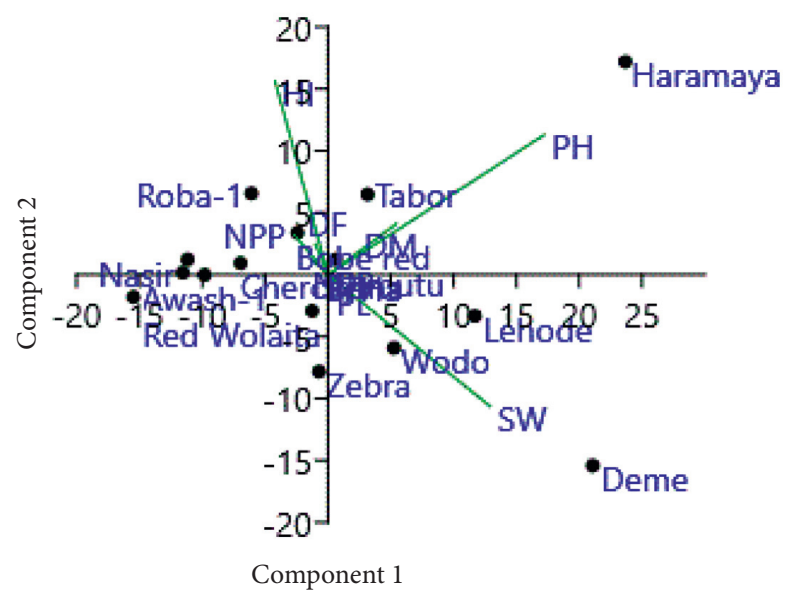

Figure 2: Correlation of traits and arrangement of 15 common bean varieties of biplot.

weight. Similarly, days to maturity are highly and positively correlated with plant height.

3.4. Genetic Progress of Seed Yield. Yield, yield advantage, and year of release for the 15 varieties are indicated in Table 9. The maximum genetic gain was obtained from variety Hawassa Dume and it has a genetic gain of $42.9 \%$ over the pioneer variety Red Wolayita. Both Hawassa Dume and Red Wolayita are small red seeded. Similar work on common bean by [25] indicated that yield increment could be between $20 \%$ and $107 \%$. Awash Melka has a yield gain of $29.4 \%$ over that of Awash $^{-1,}$ and both are small white seeded. Dimitu and Nasir with the same seed class, color, and yield potential were released in the same year. These showed that bean breeders have some weakness in yield improvement of common bean. Based on this study, breeders could not improve the yield of large-seeded beans. There is about a $12 \%$ yield penalty of Lehode over that of Wodo. Wodo was released in 2003 while Lehode was in 2009. Reference [26] reported that yield gain is very minimal in large-seeded beans.

Trend analysis of the varieties showed that a positive relationship existed between mean seed yield and year of varietal release (Figure 3). This showed that the common
TABle 9: Mean seed yield ( $\mathrm{tha}^{-1}$ ) of common bean varieties and yield increment over pioneer variety Red Wolayita.

\begin{tabular}{lccc}
\hline Varieties & Year of release & \multicolumn{2}{c}{ Seed yield in tone hectare } \\
& & Mean & \% Over Red Wolayita \\
\hline Red Wolayita & 1974 & 2.1 & \\
Roba $^{-1}$ & 1990 & 2.4 & 14.3 \\
Awash $^{-1}$ & 1990 & 1.7 & -19.0 \\
Tabor & 1998 & 2.8 & 33.3 \\
Awash Melka & 1998 & 2.2 & 4.8 \\
Zebra & 1998 & 1.5 & -28.6 \\
Dimutu & 2003 & 2.4 & 14.3 \\
Nasir & 2003 & 2.4 & 14.3 \\
Wodo & 2003 & 2.5 & 19.0 \\
Bobe red & 2006 & 2.6 & 23.8 \\
Chercher & 2006 & 2.4 & 14.3 \\
Haramaya & 2006 & 2.4 & 14.3 \\
Hawassa dume & 2008 & 3 & 42.9 \\
Deme & 2008 & 1 & -52.4 \\
Lehode & 2009 & 2.2 & 4.8 \\
\hline
\end{tabular}

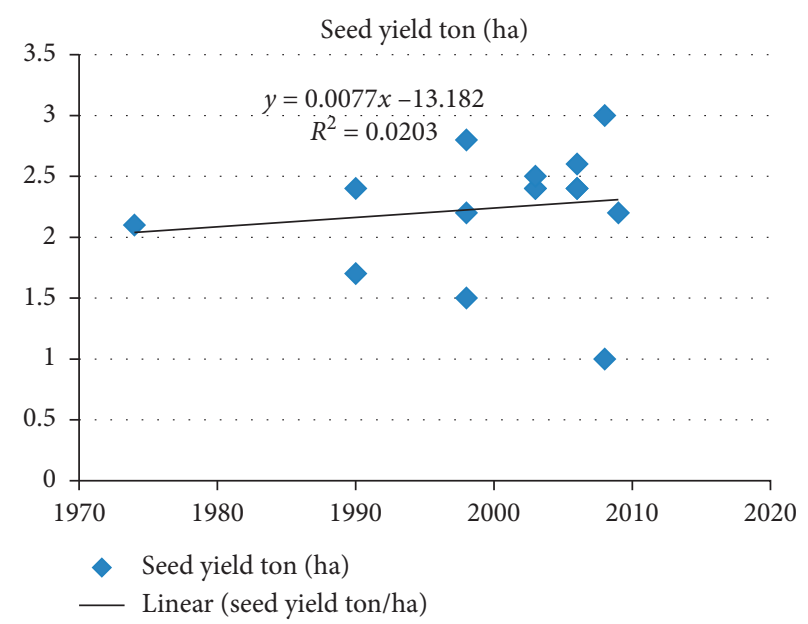

FIGURE 3: Biplot of seed yield $\left(\mathrm{tha}^{-1}\right)$ against a year of variety release in between 1974 and 2009.

bean breeding efforts in Ethiopia have resulted in a little seed yield increment of only 0.27 tonnes or an annual rate of genetic progress of $0.0077 \mathrm{t} \mathrm{ha}^{-1}\left(0.37 \% \mathrm{ha}^{-1}\right.$ year $\left.^{-1}\right)$. A study done by [25] showed a little more seed increment in common bean breeding than this study. He reported an annual seed yield increment of $0.065 \mathrm{tha}^{-1} \mathrm{year}^{-1}$. A study by [27] also indicated that there is a yield increment of $0.022 \mathrm{tha}^{-1}$ year $^{-1}$ and $0.011 \mathrm{tha}^{-1}$ year $^{-1}$ for medium and small seeded common bean varieties, respectively.

\section{Conclusion}

Overall, there is a large variation among the 15 varieties with a seed yield increment of 0.27 tonnes or an annual rate of genetic progress of $0.0077 \mathrm{tha}^{-1}\left(0.37 \% \mathrm{ha}^{-1} \mathrm{year}^{-1}\right)$ in the Ethiopian bean breeding program. The finding of the research also detected that varieties Dimitu and Nasir were similar in their market value and yield potential but released 
in the same years. On the other hand, no yield advantage was recorded on large-seeded bean varieties. Thus, the bean breeding program should reconsider the procedure of genotype evaluation and select appropriate standard check varieties.

\section{Data Availability}

Any data used to support the findings of this study are available from the corresponding author upon request.

\section{Conflicts of Interest}

The authors declare that there are no conflicts of interest in this manuscript.

\section{Acknowledgments}

The authors would like to thank the Amhara Agricultural Research Institute for funding the execution of this experiment. The authors also would like to thank Sirinka and Adet Agricultural Research Centers pulse research case team members for their important support in data collection and implementation of the experiment.

\section{References}

[1] CSA, Report on Area and Production of Major Crops during 2013/14 Meher Season, Statistical Bulletin 532, Central Statistics Agency, Addis Ababa, Ethiopia, 2014.

[2] CSA, Report on Area and Production of Major Crops during 2017/18 Meher Season, Statistical Bulletin 586, Central Statistics Agency, Addis Ababa, Ethiopia, 2018.

[3] Y. Semahegn and M. Tesfaye, "Phylogenetic relationship of lilies (lilium) analyzed based on TRNH-PSBA barcode technology," Molecular Plant Breeding, vol. 7, no. 31, pp. 1-5, 2016.

[4] M. A. Nadeem, M. Gündoğdu, S. Ercişli et al., "Uncovering phenotypic diversity and dartseq marker loci associated with antioxidant activity in common bean," Genes, vol. 11, no. 1, p. 36, 2020.

[5] H. M. Ranganatha, S. S. Patil, S. M. Manjula, and B. N. Arvindkumar, "Genetic variability studies in segregating generation of upland cotton (Gossypium hirsutum L.)," Molecular Plant Breeding, vol. 4, pp. 84-88, 2013.

[6] M. A. Nadeem, T. Karaköy, M. Z. Yeken, M. Z. Yeken et al., "Phenotypic characterization of 183 Turkish common bean accessions for agronomic, trading, and consumer-preferred plant characteristics for breeding purposes," Agronomy, vol. 10, no. 2, p. 272, 2020.

[7] J. P. Aditya, P. Bhartiya, and A. Bhartiya, "Genetic variability, heritability and character association for yield and component characters in soybean (G. max (L.) Merrill)," Journal of Central European Agriculture, vol. 12, no. 1, pp. 27-34, 2011.

[8] Ministry of Agriculture and Natural Resource, Plant Variety Release Protection and Seed Quality Control Directorate, Crop Variety Registration, Ministry of Agriculture and Natural Resource, Addis ababa, Ethiopia, 2016.

[9] P. Arora, "Genetic variability and its relevance in chickpea improvement," International Chickpea Newsletter, vol. 25, pp. 9-10, 1991.
[10] D. G. Debouck and R. Hidalgo, Morphology of the Common Bean (Phaseolus vulgaris L.), Study Guide, CIAT, Cali, Colombia, 1986.

[11] G. W. Burton and E. H. Devane, "Estimating heritability in tall fescue (festuca arundinacea) from replicated clonal material 1," Agronomy Journal, vol. 45, no. 10, pp. 478-481, 1953.

[12] H. W. Johnson, H. F. Robinson, and R. E. Comstock, "Estimates of genetic and environmental variability in soybeans," Agronomy Journal, vol. 47, no. 7, pp. 314-318, 1955.

[13] R. W. Alard, Principles of Plant Breeding, John Wiley \& Sons, Hoboken, NJ, USA, 2014.

[14] W. Wondwosen and B. Abebe, "Genetic variability, heritability and genetic advance of some haricot bean (Phaseolus vulgaris L.) varieties at Bench-Maji Zone, Southwest Ethiopia," Asian Journal of Crop Science, vol. 9, pp. 133-140, 2017.

[15] H. F. Robinson, R. E. Comstock, and P. H. Harvey, "Estimates of heritability and the degree of dominance in corn 1 ," Agronomy Journal, vol. 41, no. 8, pp. 353-359, 1949.

[16] N. Kassaye, "Studies on genetic divergence in common bean (Phaseolus vulgaris L.) introductions of Ethiopia," M.Sc. Thesis, Addis Ababa University, Addis Ababa, Ethiopia, 2006.

[17] J. Narayan, "Variability and correlation analysis in diverse genotypes of French bean (Phaseolus vulgaris L.)," M.Sc. Thesis, Banaras Hindu University, Varanasi, India, 2013.

[18] P. Singh and S. S. Narayanan, Biometrical Techniques in Plant Breeding, Kalayani Publishers, New Dehli, India, 1st edition, 2013.

[19] M. S. D. Lima, J. E. D. S. Carneiro, P. C. S. Carneiro, C. S. Pereira, R. F. Vieira, and P. R. Cecon, "Characterization of genetic variability among common bean genotypes by morphological descriptors," Crop Breeding and Applied Biotechnology, vol. 12, no. 1, pp. 76-84, 2012.

[20] L. Sinkovic, B. P. E. Sinkovic, and V. Meglic, "Morphological seed characterization of common (Phaseolus vulgaris L.) and runner (Phaseolus coccineus L.) bean germplasm: a slovenian gene bank example," Biomed Research International, vol. 2019, Article ID 6376948, , 2019.

[21] O. T. Villela, S. H. V. Trevisoli, F. M. Silva, L. S. B. Junior, and A. O. Mauro, "Genetic divergence of roundup ready RR soya bean cultivars estimated by phenotypic characteristics and molecular markers," African Journal of Biotechnology, vol. 13, no. 26, pp. 2613-2625, 2014.

[22] M. A. Adebisi, F. S. Okelola, M. O. Ajala, T. O. Kehinde, I. O. Daniel, and O. O. Ajani, "Evaluation of variations in seed vigour characters of West African rice," American Journal of Plant Sciences, vol. 4, no. 2, pp. 356-363, 2013.

[23] W. Yan and M. S. Kang, GGE-biplot Analysis: A Graphical Tool for Breeders, Geneticists, and Agronomists, CRC Press, Boca Raton, FL, USA, 2003.

[24] W. Yan and I. Rajcan, "Biplot analysis of test sites and trait relations of soybean in Ontario," Crop Science, vol. 42, pp. 11-20, 2002.

[25] B. Kebere, B. Ketema, and S. Prapa, "Genetic gain in grain yield potential and associated agronomic traits in haricot bean (Phaseolus vulgaris L.)," Kasetsart Journal of Natural Science, vol. 40, pp. 835-845, 2006.

[26] A. Berhanu, N. Kassaye, and S. Tigist, "Progress of common bean breeding and genetics research in Ethiopia," Ethiopian Journal of Crop Science, vol. 6, pp. 116-128, 2018.

[27] S. Bekele, F. Mekbeb, G. Keneni, and B. Amsalu, "Genetic progress for yield and yield components of common bean (Phaseolus vulgaris L.) in Ethiopia," M.Sc thesis, Haremaya University, Dire Dawa, Ethiopia, 2016. 